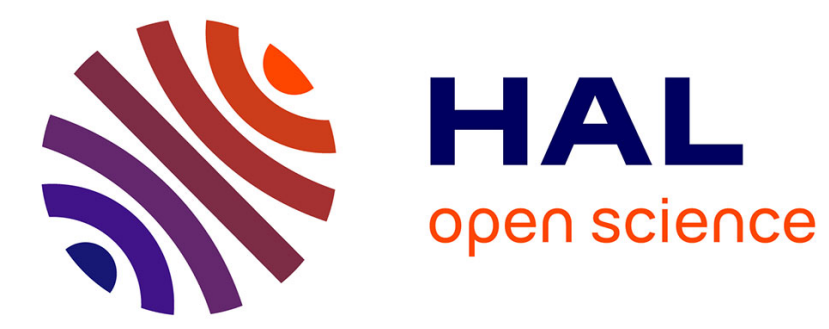

\title{
NEW ACOUSTIC SENSORS
}

\author{
G. Sessler
}

\section{To cite this version:}

G. Sessler. NEW ACOUSTIC SENSORS. Journal de Physique IV Proceedings, 1992, 02 (C1), pp.C1413-C1-419. 10.1051/jp4:1992189 . jpa-00251261

\section{HAL Id: jpa-00251261 https://hal.science/jpa-00251261}

Submitted on 1 Jan 1992

HAL is a multi-disciplinary open access archive for the deposit and dissemination of scientific research documents, whether they are published or not. The documents may come from teaching and research institutions in France or abroad, or from public or private research centers.
L'archive ouverte pluridisciplinaire HAL, est destinée au dépôt et à la diffusion de documents scientifiques de niveau recherche, publiés ou non, émanant des établissements d'enseignement et de recherche français ou étrangers, des laboratoires publics ou privés. 


\title{
NEW ACOUSTIC SENSORS
}

\author{
G.M. SESSLER \\ Technical University Darmstadt, Merckstrasse 25, D-6100 Darmstadt, Germany
}

\begin{abstract}
New developments in the field of microphones or acoustic sensors, based on the silicon, optic-waveguide, and polymer technologies are discussed. The silicon sensors are produced on silicon wafers with micromechanical methods. Subminiature transducers of this kind, utilizing the condenser or piezoelectric principles, are made with membranes of about $1 \mathrm{~mm}^{2}$ area and less than $1 \mu \mathrm{m}$ thickness. Optic-waveguide sensors employ glass fibers or waveguides on glass or polymer substrates and detect phase or intensity modulations of the transmitted light caused by the sound waves. Polymer sensors utilize polymer electrets or piezopolymers, usually as thin membranes or layers. Polymer electret sensors find widespread applications as microphones and ultrasonic transducers. New developments include the use of electret biasing in silicon sensors and the design of electret-microphone arrays. Piezoelectric polymer sensors are being improved by the use of better materials and by innovative poling techniques, such as monomorph poling. Of interest are also hybrid sensors using silicon structures covered with piezoelectric polymer layers.
\end{abstract}

\section{Résumé}

Les développements nouveaux dans le domaine de microphones ou senseurs acoustiques, basés sur les technologies de silicium, de guide d'ondes optiques et de polymères, sont discutés. Des senseurs au silicium ont été produits sur les couches de silicium par les méthodes micromécaniques. Les transducteurs superminiaturisés de ce type qui utilisent les principes de microphones capacitifs ou de couches piézoélectriques, sont construits avec des membranes à $1 \mathrm{~mm}^{2}$ de grandeur et moins de $1 \mu \mathrm{m}$ d'épaisseur. Les senseurs à guide d'ondes optiques sont généralement produits soit de fibre optique soit de guide d'ondes sur glace ou de substrats de polymères et détectent la modulation de phase ou d'intensité de la lumière transmise, produite par l'onde acoustique de son. Les senseurs aux polymères employés comme des électrets ou piézopolymères, sont généralement présentés par des membranes ou des couches minces. Les senseurs aux électrets-polymères ont beaucoup d'applications commes des microphones et des transducteurs ultrasoniques. Les développements nouveaux à ce domaine-là sont liés à l'utilisation soit de la polarisation d'électrets chez les senseurs au silicium soit des réseaux de microphones à l'électret. Des senseurs aux polymères piézoélectriques sont optimisés par des nouvelles techniques de polarisation, par exemple par la polarisation monomorphe. Il serait intéressant d'utiliser les senseurs hybrides composés de membrane au silicium couvert par des couches de polymères. 


\section{Introduction}

During the last decade, a number of interesting and significant innovations have occurred in the field of acoustic sensors, a term now often used for modern microphones in the audio and ultrasonic ranges. Most prominent were the developments in the areas of silicon, optic waveguide, and polymer transducers.

The progress in the field of silicon transducers can be attributed to a systematic application of the methods of micromechanics to the production of tiny sensor structures. Optic waveguide transducers for acoustic sensing are possible because means were found to effectively modulate the propagation of light in glass fibers or other optic waveguides by sound waves. Finally, the advances in the field of polymer transducers are directly related to progress in material science and technology, for example to improvements of piezopolymers and of poling methods required to induce piezoelectricity in these materials.

In the following, a short review of new developments in the three fields of acoustic sensing is given. At the end of the article, a brief discussion of the merits and future uses of these sensors is ventured.

\section{Acoustic silicon sensors}

Such sensors are made with the methods of silicon technology, as they are customary for the production of microelectronic components [1]. Among these methods are doping-, deposition-, oxidation-, and lithography processes and, as key technologies, anisotropic etching such as plasma etching or wet-chemical etching. The utility of the wet-chemical methods is, among others, based on the fact that the etch rates for silicon dioxide or properly doped silicon are considerably smaller than those for silicon. The anisotropic etching methods allow one to produce holes, pits, recesses, membranes and cantilever beams. The methods in their entirety, if used to make such structures, are referred to as micromechanics. If micromechanic sensors are combined with microelectronic components for signal processing on the same chip, an integrated sensor is obtained.

The first microphones designed with these methods were described in 1983 [2,3]. Since then, a number of micromechanical acoustic sensors, based on the piezoelectric, condenser and modulated FET principles have been developed. Most of these are for the audio range [4-17], some for use at ultrasonic frequencies $[18,19]$. Typical data for the sensors for the audio range are listed in Table 1.

\begin{tabular}{|c|c|c|c|c|c|c|}
\hline $\begin{array}{l}\text { Author,Yoar } \\
\text { Reterenoe }\end{array}$ & $\begin{array}{l}\text { Transducer } \\
\text { Prinelple }\end{array}$ & $\begin{array}{l}\text { Membrane } \\
\text { Material, } \\
\text { Size (mm) }\end{array}$ & $\begin{array}{l}\text { Reaonance } \\
\text { Frequency } \\
\text { (kHz) }\end{array}$ & $\begin{array}{l}\text { Sensilivity } \\
(m Y / P a)\end{array}$ & $\begin{array}{l}\text { Equivalent } \\
\text { Nolse } \\
\text { Level (dBA) }\end{array}$ & $\begin{array}{l}\text { Capacitance } \\
\text { or } \\
\text { Impedance }\end{array}$ \\
\hline $\begin{array}{l}\text { Royer, } 1983 \\
\text { [3] }\end{array}$ & $\begin{array}{l}\text { piezoelectric } \\
\text { (3 } \mu \mathrm{m} \text { ZnO) }\end{array}$ & $\begin{array}{l}30 \mu \mathrm{m} \mathrm{SI} \\
3 \times 3\end{array}$ & $\sim 40$ & 0.25 & 68 & \\
\hline $\begin{array}{l}\text { Hohm } 1985 \\
{[4,8]}\end{array}$ & $\begin{array}{l}\text { condenser } \\
\text { (28 V blas) }\end{array}$ & $\begin{array}{l}0.15 \mu \mathrm{m} \mathrm{Sl} \mathrm{N}_{4} \\
0.8 \times 0.8\end{array}$ & $>20$ & 4.3 & 54 & $1.4 \mathrm{pF}$ \\
\hline $\begin{array}{l}\text { Mutler } 1987 \\
{[6]}\end{array}$ & $\begin{array}{l}\text { plezoelectric } \\
(0.3 \mu \mathrm{m} \text { ZnO) }\end{array}$ & ${ }_{3 \times 3}^{2 \mu \mathrm{m}} \mathrm{Si}_{3} \mathrm{~N}_{4}$ & 7.8 & 0.05 & 72 & $26 \mathrm{pF}$ \\
\hline $\begin{array}{l}\text { Franz } 1988 \\
{[7]}\end{array}$ & $\begin{array}{l}\text { piezoelectric } \\
(0.2 \mu \mathrm{m} \text { AIN) }\end{array}$ & $\begin{array}{l}0.8 \mu \mathrm{m} \text { doped Si } \\
0.8 \times 0.9\end{array}$ & 45 & 0.025 & 68 & $75 \mathrm{pF}$ \\
\hline $\begin{array}{l}\text { Voorthuyzen } \\
1989 \\
{[9]}\end{array}$ & $\begin{array}{l}\text { electret } \\
\left(1.1 \mu \mathrm{m} \mathrm{Sl}_{2}\right)\end{array}$ & $\begin{array}{l}2.5 \mu \mathrm{m} \text { Mylar } \\
2.45 \times 2.45\end{array}$ & 15 & 18 & & \\
\hline $\begin{array}{l}\text { Murphy } 1989 \\
{[10]}\end{array}$ & $\begin{array}{l}\text { electret } \\
(1.5 \mu \mathrm{m} \mathrm{Si0} \\
\text { or } 12 \mu \mathrm{m} \mathrm{FEP}\end{array}$ & $\begin{array}{l}1.5 \mu \mathrm{m} \text { Polyester } \\
3 \times 3\end{array}$ & $>15$ & $4-8$ & $\sim 30$ & $2 \mathrm{pF}$ \\
\hline $\begin{array}{l}\text { Bergqvist } 1890 \\
\text { [11] }\end{array}$ & $\begin{array}{l}\text { condenser } \\
\text { (16 V bias) }\end{array}$ & $\begin{array}{l}5 \mu \mathrm{m} \text { doped } \mathrm{SI} \\
2 \times 2\end{array}$ & $\begin{array}{c}4 \\
16\end{array}$ & $\begin{array}{l}13 \\
1.4\end{array}$ & 31,5 & $3.5 \mathrm{pF}$ \\
\hline $\begin{array}{l}\text { Kühnel } 1992 \\
\text { [15] }\end{array}$ & FET & $\begin{array}{l}0.15 \text { H.m doped } \\
\text { Si, } 0.7 \times 1.3\end{array}$ & $>20$ & $\stackrel{5}{(\text { at } 1 \mathrm{k} \Omega})$ & 62 & ikn \\
\hline $\begin{array}{l}\text { Kühnel } 1992 \\
\text { [15] }\end{array}$ & $\begin{array}{l}\text { condenser } \\
(28 \mathrm{~V} \text { bias) }\end{array}$ & $\begin{array}{l}0.15 \mu \mathrm{mSl}_{3} \mathrm{~N}_{4} \\
0.8 \times 0.8\end{array}$ & $>20$ & 10 & $<25$ & $1.1 \mathrm{pF}$ \\
\hline
\end{tabular}

Table 1: Micromechanical Silicon Transducers 

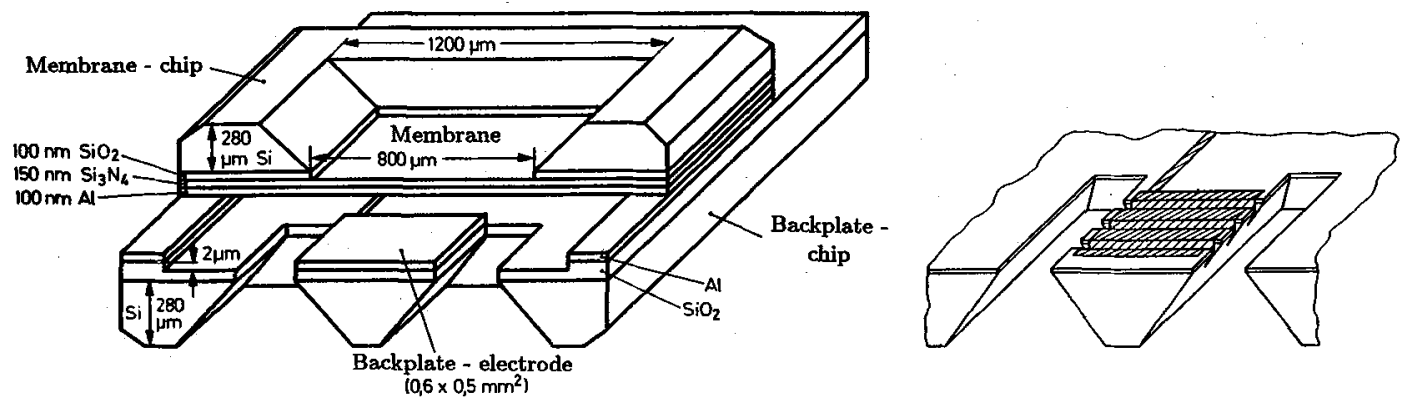

Fig. 1: Left: Schematic view of subminiature condenser microphone. Front parts of membrane and backplate chips removed for better view of other parts of microphone [8]. Right: Improved backplate with grooves for use in the above microphone [15].

The first subminiature microphone with a membrane area of less than $1 \mathrm{~mm}^{2}$ was of the condenser type $[4,8]$. This sensor consists of a backelectrode chip and a membrane chip glued together, as shown in Fig. 1, left. A $2 \mu \mathrm{m}$ air gap remains between membrane and backplate. To reduce the stiffness of the air gap, it is connected to a larger back cavity by two slits, as seen in the Figure. Thus, membrane deflections result in streaming of air in the thin air gap, which introduces damping. This causes a loss in sensitivity at higher frequencies. For a microphone with a cutoff at about $2 \mathrm{kHz}$, the low-frequency, open circuit sensitivity is $4,3 \mathrm{mV} / \mathrm{Pa}$.

The drawback of the air gap damping, which is typical for condenser microphones, can be eliminated in various ways. One approach utilizes the fact that this damping is inversely proportional to the third power of the air-gap thickness. A number of designs use air gaps of 5 to 20 $\mu \mathrm{m}$ thickness and have therefore greatly reduced damping [9-11]. Since these transducers are also relatively large, with membrane dimensions of at least $2 \times 2 \mathrm{~mm}^{2}$, their equivalent noise levels are as low as about $30 \mathrm{~dB}(\mathrm{~A})$ and thus lower than those of the older, smaller systems $[4,8]$.

Another approach to reduced air-gap damping consists in an improvement of the backplatesurface structure such that streaming losses are diminished. A view of such a modified backplate is shown in Fig. 1, right [15]. This backplate differs from the one shown in Fig. 1, left in the sense that the center area has grooves of triangular cross section, about $80 \mu \mathrm{m}$ wide at the top and $56 \mu \mathrm{m}$ deep. As the membrane is deflected, the air can now stream into the grooves and along these into the slits with very small resistance.

The measured frequency responses in $\mathrm{dB}$ re $1 \mathrm{~V} / \mathrm{Pa}$ of several microphones according to Fig. 1 , left with the backplate of Fig. 1, right are shown in Fig. 2. Parameter is the boron implantationdose of the membrane which determines its intrinsic tension; a high implantation dose considerably reduces the tension and thus results in higher sensitivity and in a lower resonance frequency which is, however, still well above $20 \mathrm{kHz}$. The resultant sensitivity is now constant up to at least $20 \mathrm{kHz}$ and amounts to $1.7 \mathrm{mV} / \mathrm{Pa}$ for curve a, corresponding to an open-circuit value of $7.3 \mathrm{mV} / \mathrm{Pa}$. The large reduction in sensitivity is due to a loading by parallel capacitances. The measured equivalent noise level for this microphone is less than $25 \mathrm{~dB}(\mathrm{~A})$ and thus comparable to that of conventional condenser microphones.

Recently, backplates have been designed which diminish air gap damping by employing a larger number of holes and which simultaneously reduce parallel capacitance by using implanted pnjunctions [15]. In this implementation, 144 holes of $35 \times 35 \mu \mathrm{m}^{2}$ area are etched into a $13 \mu \mathrm{m}$ thick backplate which is supported by four pn-junctions of low capacitance and high resistance. Such microphones promise to have even better sensitivities and reduced equivalent noise levels.

Silicon condenser microphones have recently been made with electret biasing supplied by silicon dioxide electrets $[9,10]$. The electret properties of $\mathrm{SiO}_{2}$ are excellent if the material is pretreated to reduce surface conductivity $[20,21]$. Silicon dioxide electrets have been used in electret microphones of more conventional design as early as 1984 [22]. In other silicon microphones, Teflon FEP was used as an electret material (see below).

Another capacitive microphone is the so called FET-microphone, shown in Fig. 3, [12,13]. It is also a two-chip structure which consists (1) of a backplate chip carrying on a ridge the source and drain regions together with the p-doped channel of an MOS transistor and (2) of a membrane chip consisting of a metalized silicon nitride membrane which serves as the gate. The membrane vibra- 


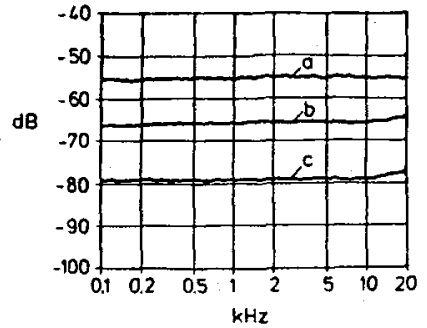

Fig. 2: Sensitivity in $\mathrm{dB}$ re $1 \mathrm{~V} / \mathrm{Pa}$ for three condenser microphones of the design shown in Fig. 1 [15], with membranes having the following boron implantation

a: $9 \times 10^{14} \mathrm{~cm}^{-2}$, b: $5 \times 10^{14} \mathrm{~cm}^{-2}$, c: $10^{14} \mathrm{~cm}^{-2}$ The sensitivities are loaded values. Opencircuit sensitivities are by factor 4.3 higher.

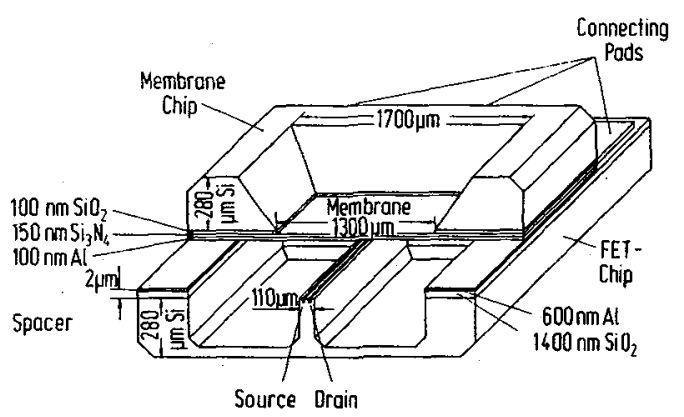

Fig. 3: Schematic view of FET microphone [13].

tions modulate the gate-channel capacitance and thus the drain current. Although the air gap between membrane and gate oxide is only $2 \mu \mathrm{m}$ thick, the narrow source-drain ridge (110 $\mu \mathrm{m}$ ) prevents large air gap damping.

New experimental results on such a microphone yield a transducer sensitivity of about $5 \mathrm{mV} / \mathrm{Pa}$ in the frequency range 0.1 to $30 \mathrm{kHz}$. The equivalent noise level is $62 \mathrm{~dB}(\mathrm{~A})$.

Piezoelectric silicon microphones, having the advantage of being one-chip transducers with no air gap losses, were described early $[2,6,7]$. These older designs were made with $\mathrm{ZnO}$ and AIN piezoelectric layers and had relatively low sensitivities and relatively high equivalent noise levels (see Table 1). Recently, piezoelectric silicon microphones with piezopolymer layers spin-coated onto silicon membranes have been made. [16]. These show promise of better acoustic performance. Alternatively, transducers consisting of piezoresistive layers on silicon membranes are now being investigated with respect to their electroacoustic properties [17].

The data shown in Table 1 and discussed above indicates that silicon microphones can now be made with sufficiently high sensitivity and small equivalent noise level to be of practical use.

\section{Optical-waveguide sensors for acoustics}

Such microphones depend on the fact that sound waves cause a phase- or intensity modulation of light waves in an optical fiber or other optical waveguide. Phase modulation is due to the pressure sensitivity of the optical phase constant of a glass fiber and can be detected in an interferometric setup as shown, e. g., in Fig. 4a. On the other hand, intensity modulation of the transmitted light may be obtained, according to Fig. 4 b, by directing a light beam emitted from a transmitting fiber after reflection from a vibrating membrane into a receiving fiber. Because of the strong temperature dependence of light propagation in a fiber, phase-modulating transducers tend to instability and require therefore compensating measures. In addition, such systems need as a light source lasers of good stability. As opposed to this, intensity-modulating transducers are insensitive to temperature fluctuations and can be operated with LED's; they are therefore usually much simpler devices.

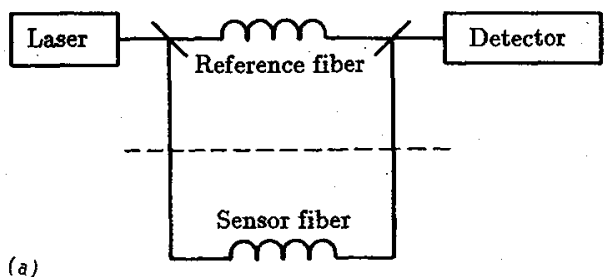

(a)

Fig. 4:

Schematic of the design of phase-modulating (a) and intensity-modulating (b) glass fiber sensors.

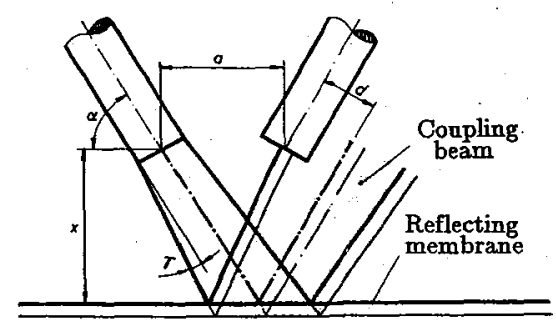

(b)

(n) 


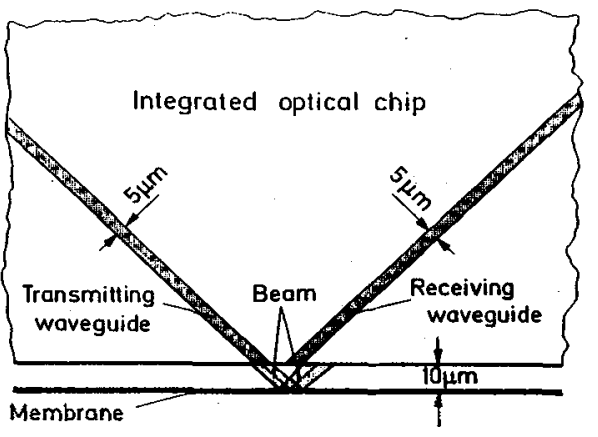

Fig. 5: Schematic view of integrated optical-waveguide microphone [32].

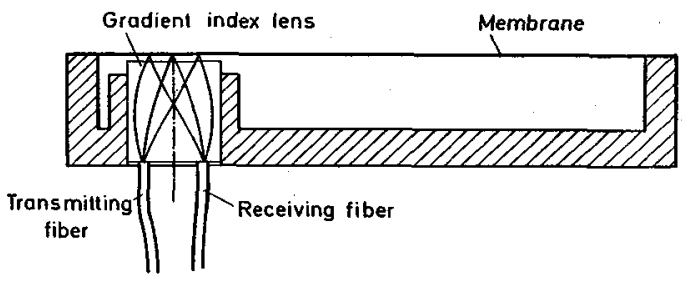

Fig. 6: Schematic view of fiber-optic microphone with gradient-index lens [30].

Since the first realization of a glass-fiber sensor in 1977, a large number of phase- or intensitymodulating systems for the detection of waterborne sound have been described [23]. Also, microphones for airborne sound have been realized with optical sensors [24-33]. In the following, a few recently developed optic-waveguide sensors for airborne sound, all based on intensity modulation, will be discussed.

One such device represents a modification of the transducer illustrated schematically in Fig. 4b: Instead of the two fibers, an optical chip whose surface carries two waveguides is used, as illustrated in Fig. 5 [31,32]. This arrangement simplifies the adjustment problems encountered with the system in Fig. 4b: Rather than controlling the mutual arrangement of three components (two fibers and a membrane), only the distance of the chip from the membrane has to be adjusted. Another advantage is the shorter pathlength of the light beam in air which results in a smaller geometric beam broadening and thus in larger sensitivity. The waveguides can be made by ion implantation or by photo-locking on polymer substrates.

A related design which utilizes the focussing of the light beam emerging from a transmitting fiber onto a receiving fiber by means of a gradient-index lens is shown in Fig. 6 [31,32]. Since the deflection of the beam is sensitive to the angular excursion of the membrane, the lens is optimally placed close to the margin of the membrane.

Since optical-waveguide microphones yield an optical output, their sensitivity can not be compared directly with that of electro-acoustic transducers. However, a quantity that allows comparison is the equivalent noise level. This is located for present-day intensity-modulating sensors with bandwidths of $5 \mathrm{kHz}$ or more at about $40 \mathrm{~dB}(\mathrm{~A})$ if the laser noise is compensated [32]. These values are not yet as low as those for the best silicon microphones listed in Table 1 . But there is hope that the noise levels of optical-waveguide sensors can be further lowered with improved noise compensation.

\section{Acoustic polymer sensors}

These are sensors in which electrically charged or poled polymers are used [34]. One such group are polymer-electret sensors where charged films of, e.g., Teflon are incorporated into condenser

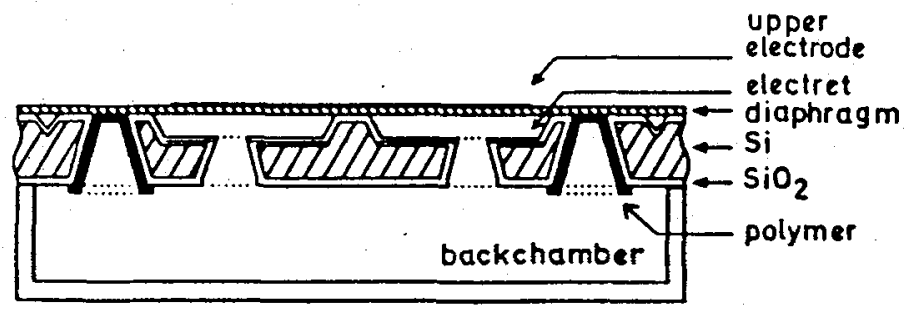

Fig. 7: Cross-sectional view of silicon-microphone with Teflon electret [9]. 

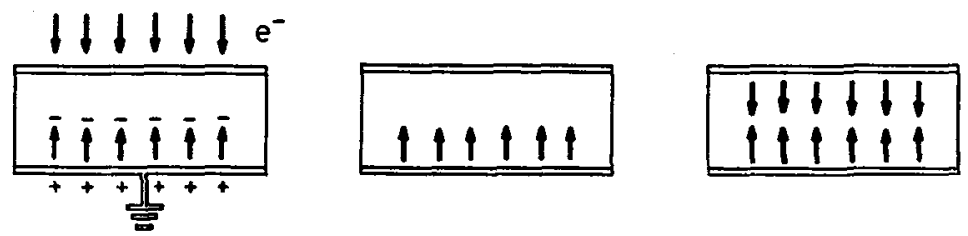

Fig. 8: Electron-beam polarisation of piezopolymer film (left) resulting in monomorph (center) or bimorph (right).

transducers as membrane or as layer on the back electrode to replace the bias which is normally needed in such systems. A second group are piezopolymer transducers which contain a poled polymer, such as polyvinylidenefluoride (PVDF) or one of its copolymers, as piezoelectric element.

Polymer-electret transducers represent nowadays, after a rapid development in the 1970's, a mature technology with only few innovations. Such sensors are widely used as microphones, ultrasonic transducers and, more recently, as elements in directional arrays [34]. A very new development is the use of Teflon electrets in competition with silicon dioxide electrets (see above) in silicon microphones $[9,10]$. Such a transducer with a charged Teflon layer on the backplate is shown in Fig. 7.

Until the early 1980's, the preferred piezopolymer material was PVDF. Since then, copolymers of PVDF with Trifluoroethylene P(VDF-TrFE) were investigated and were shown to have larger piezoelectric activity. While PVDF has typical coefficients $d_{31}=20 \mathrm{pC} / \mathrm{N}$ and $\mathrm{k}_{31}=0.16, \mathrm{P}$ (VDFTrFE) has stable values of $d_{31}=30 \mathrm{pC} / \mathrm{N}$ and $\mathrm{k}_{31}=0.20$ [35].

Piezopolymer microphones consist mostly of films with uniform piezoelectric activity in the thickness direction. These transducers work as bending devices if they are arranged in a curved geometry with clamped edges [36]. Microphones with plane geometry are possible if one uses monomorphs or bimorphs. Such piezoelements are usually composed of two properly poled films which are cemented together [37] or of a polymer film deposited on a silicon membrane [16].

However, monomorphs and bimorphs can also be made from a single film by means of electronbeam poling $[38,39]$. This is possible by selecting the beam energy such that the electrons are deposited in the center of the film, as shown in Fig. 8. The electric field between electron layer and grounded rear electrode polarizes the corresponding part of the film, resulting in a monomorph. If the film is subsequently exposed to an electron beam from the other side, a bimorph is formed.

Such elements can be directly used as microphones in plane geometry. Prototypes show sensitivities of $0.5 \mathrm{mV} / \mathrm{Pa}$ at bandwidths of $4 \mathrm{kHz}$ [40]. An increase in sensitivity is possible if more highly-poled films are used.

Piezoelectric polymers are extensively used in hydrophones and have been under study for use in ultrasonic devices for some time [35]. Of recent interest are devices in which a piezoelectric transducer is directly coupled to the gate of an MOS transistor to modulate the drain current when exposed to an acoustic wave $[18,19]$. Such transducers can serve as elements in ultrasonic imaging arrays, particularly when they are miniaturized by the use of micromachining methods.

\section{Conclusions}

In conclusion, the merits of the various acoustic transducer groups will be discussed.

Acoustic silicon sensors are miniature transducers with small vibration sensitivity which can be produced inexpensively with the methods of microelectronics. Another advantage is that the signal processing electronics can be integrated with the sensor in the same manufacturing process. Such microphones will be used in the future wherever small size, small vibration sensitivity, and low price are important.

Optic-waveguide sensors deliver an optical rather than an electric output signal. They are therefore better matched to optic transmission systems, such as the future telephone system, than conventional microphones. Another advantage is their insensitivity against electromagnetic interference. Applications of such microphones are expected as soon as their equivalent noise level can be lowered to the values typical for other transducers and if they can be build in miniaturized form.

Polymer-electret microphones are nowadays dominating the field of acoustic transduction. A combination with the silicon technology will favorably influence quality and price of these sensors. As opposed to this, piezopolymer transducers are not being used as audio microphones, although 
they are common as hydrophones and ultrasonic sensors. Use in microphones is likely if monomorphs or bimorphs with high piezoelectric oefficients are available which can be employed in plane geometry.

\section{References}

[1] K. E. PETERSEN, IEEE Proc., 70 (1982) 420 - 457.

[2] M. ROYER, J. O. HOLMEN, M. A. WURM, O. S. AADLAND, and M. GLENN, Sensors and Actuators, 4 (1983) 357 - 362.

[3] D. HOHM and G. M. SESSLER, Proc. 11th Internat. Congress on Acoustics, Paris, 1983, Vol. 6 , pp. $29-32$.

[4] D. HOHM, Fortschritte der Akustik, DAGA '85, pp. 847 - 850.

[5] T. L. POTEAT and I. J. BUSCH-VISHNIAC, Proc. 12th Internat. Congress on Acoustics, Toronto 1986, Vol. III, pp. L1-2.

[6] R. S. MULLER, Proc. 4th Internat. Conf. on Solid State Sensors and Actuators (Transducers '87) 1987, pp. 107 - 111.

[7] J. FRANZ, VDI-Berichte Nr. 677 (1988), pp. 299 - 302.

8 D. HOHM and G. HESS, J. Acoust. Soc. Amer., 85 (1989) $476-480$.

[9] J. A. VOORTHUYZEN, P. BERGVELD, and A. J. SPRENKELS, IEEE Trans. Electric. Insulation, 24 (1989) 267 - 276.

[10] P. MURPHY, K. HÜBSCHI, N. DE ROOIJ, and C. RACINE, IEEE Trans. Electric. Insulation, 24 (1989) 495 - 498.

[11] J. BERGQVIST and F. RUDOLF, Sensors and Actuators, A21-A23 (1990) 123 - 125.

12 W. KÜHNEL, Fortschritte der Akustik, DAGA ' 88 , pp. 509 - 512.

13 W. KÜHNEL, Sensors and Acutators, A25-27 (1991), 521 - 525.

14 W. KÜHNEL, J. FRANZ, D. HOHM, and G. HESS, Acustica 73 (1991), 90 - 99.

15. W. KÜHNEL, Sensors and Actuators, to be published.

[16] R. SCHELLIN, G. HESS, W. KÜHNEL, G. M. SESSLER, and E. FUKADA, Proc. 7th Internat. Symposium on Electrets, 1991, pp. 929 - 934.

[17. R. SCHELLIN and G. HESS, Sensors and Actuators, to be published.

18] A. S. FIORELLO, J. VAN DER SPIEGEL, P. E. BLOOMFIELD, and D. ESMAIL-ZANDI, Sensors and Actuators, A21-A23 (1990) 719 - 725.

[19] JIAN-HUA MO, A. L. ROBINSON, and F. L. TERRY, JR., Sensors and Actuators, A21-A23 (1990) $679-682$.

[20] J. A. VOORTHUYZEN, W. OLTHUIS, P. BERGVELD, and A. J. SPRENKELS, IEEE Trans. Electric. Insulat., 24 (1989) 255 - 266.

[21] P. GUNTHER, IEEE Trans. Electric. Insulat. 24, (1989) 439 - 442; ibid. 26 (1991) 42 - 48.

22. D. HOHM and R. GERHARD-MULTHAUPT, J. Acoust. Soc. Amer. 75 (1984) $1297-1298$.

23] T. G. GIALLORENZI, J. A. BUCARO, A. DANDRIDGE, G. H. SIEGEL, J. H. COLE, S. C. RASHLEIGH, and R. G. PRIEST, IEEE J. Quantum Electron. QE-18 (1982) 626 - 665.

[24] I. FROMM, Frequenz 32 (1978) 356 - 363.

25. R. HERBER, Fernseh- und Kinotechnik, 40 (1986) 309 - 312.

26 D. GARTHE, Fortschritte der Akustik, DAGA '89, pp. 175 - 178.

27] K. FUJIMURA, M. MATSUMOTO, K. HATTORIE, and H. NAONO, J. Acoust. Soc. Amer. 84 (1988) S102.

[28] R. HERBER, VDI Fortschritt-Berichte, Reihe 10, Nr. 125 (1990), pp. 40 - 78.

29. D. GARTHE and M. MORWEISER, Fortschritte der Akustik, DAGA '90, pp. 281 - 284.

30. D. GARTHE and U. SCHNEIDER, Fortschritte der Akustik, DAGA '90, pp. 277 - 280.

31. D. GARTHE, Acustica 73 (1991), 72 - 89.

32 D. GARTHE, Sensors and Actuators, A25-27 (1991), 341 - 345.

33. W. LUKOSZ and P. PLISKA, Sensors and Actuators A25-27 (1991), 337 - 340.

[34] G. M. SESSLER, Editor, Topics in Applied Physics, Vol. 33, "Electrets", Springer Verlag, Heidelberg, 2nd edition., 1987.

[35] T. T. WANG, J. M. HERBERT, and A. M. GLASS, Eds., "The applications of ferroelectric polymers", Blackie, Glasgow 1987.

[36] R. LERCH, NTZ-Árchiv 7 (1985) 145 - 154.

37 G. M. GARNER, Systems Technology 27 (1977) $22-25$.

[38] B. GROSS, R. GERHARD-MULTHAUPT, A. BERRAISSOUL, and G. M. SESSLER, J. Appl. Phys. 62 (1987) 1429 - 1432.

[39] G. M. SESSLER and A. BERRAISSOUL, IEEE Trans. Electric. Insulat. 24 (1989) 249 - 254.

[40] G. YANG and G. M. SESSLER, (to be published). 